\title{
Student Employees in Academic Libraries
}

\begin{abstract}
As part of the American higher education system, college and university libraries are subject to the same restless disruption as the rest of the campus. In view of this turmoil, the present paper considers the potential role of student library employees in successful library management. Suggestions are made which can help to minimize dissatisfaction among library student assistants and improve their ability to contribute to the library enterprise.
\end{abstract}

A t a time when students throughout the country are concerned and agitating for more personal involvement and responsibility, it seems appropriate to ask what responsible voice a student might have in the management of college and university libraries. This question has already been discussed in the literature as it relates to student library committees (CRL, November 1965), but there has been limited published discussion of the role of the student employee in libraries.

The expression "responsible voice" is at best vague and abstract, and it might be more appropriate to set up an objective like "achieving the maximum potential of student employees for library efficiency," or "personal personnel recognition for more effective library administration." At least with these we could get some measurement of whether or not our aims were being accomplished. However, "responsible voice" should not be put aside lightly, because it has an implied relationship with the success of student personnel participation. It can relate directly to a student's outlook on libraries when he is

Keith M. Cottam is Social Science Librarian at Brigham Young University. hired into a library, the way his attitude toward the responsibilities of his job progresses, and the way he views the functions of the library when he leaves.

For example, a student knows better than anyone else what interests him and how some things can be accomplished, and this can critically affect the amount of energy and effort he is willing to expend. Much time can be spent in trying to get people to do something they do not want to do. On the other hand, if a student assistant recognizes the importance of something and decides for himself that it is worth doing-or better, discovers a way to improve upon itthere is little need to motivate him or to establish irrelevant standards. The problem then for administrators becomes one of capturing the imagination and interest of the student assistants.

Surely there are objections which can be raised against student workers participating to any substantial degree in the actual problems of library administration, among which are doubtless their immaturity and lack of depth in understanding library management. However, there are certainly also some problems in relying entirely upon professionally mature librarians or fully experienced clerical assistants for all decision making. The immaturity of students is pre- 
cisely the reason why they should be given a voice. They cannot possibly grow in their understanding of themselves or of their library opportunities without new challenges.

The fact that libraries change slowly always leaves some librarians conditioned by old-fashioned images and fears that can only threaten innovative and creative librarianship. Even in our controversial times intellectual, involved, and committed librarians in many situations still end up struggling against influences which restrict creativity and produce conformity. The general state of the library profession, restrictive administrative conditions, status consciousness, the threat of internal or external controversy, personal insecurity, and perhaps most important, the personality traits of librarians themselves all combine to form a complex system which often seems to impede the progress of all but the most persistent among us. Students working in libraries naturally find themselves at the bottom of this pile, with very little recourse unless a conscientious effort is made to aid them. They are often to all appearances trapped, and one might well ask just what can be done about it.

First, the majority of American college students have always manifested optimism, faith, and hope in a future full of opportunity for anyone with sufficient drive and integrity to take advantage of it. Libraries can apply that dynamic spirit as well as their ingenuity, energies, and willingness to work on the most difficult problems and situations. The opportunity is there if librarians will but delegate responsibility to those student assistants who have the capacity to assume it prudently. Librarians, of course, must remain scrupulously within the limitations of their own level of responsibility, but they can at the same time permit wide exercise of initiative and freedom of action on the part of the student assistants who look to them for direction. The contributions of student assistants may take many forms: new perspectives on and possibly even solutions to longstanding problems, improvements on traditional procedures, or a fresh outlook on policies which may be having an adverse effect on the academic community in general, as well as on themselves as students and employees.

The second thing that can be done grows from recognition of the fact that higher education does not end in the classroom. Indeed, it can sometimes best be attained through the application of knowledge in meeting new situations, through venture into new experiences, and through realistic exchange of ideas. Librarians can foster this kind of experiential education of their student assistants by encouraging them in selfdiscipline and informative communication. Students should be given significant tasks in their library experience, work which provides them with responsibilities commensurate with their abilities and is capable of promoting critical analysis and decision making. They can be successfully given direct contact with the public through information desks and other service points, they can plan and coordinate many different types of projects and programs, they can supervise fellow students, they can work with communications through such things as staff bulletins and committee meetings, they can do creative work with displays, and they can compile bibliographies. This involvement can enhance library service as the talents of participating students continue to grow and develop.

Third, student assistants can be accepted as colleagues-as companions in learning-and the serious and capable student will both profit from and contribute to it. There are, of course, extremist attitudes and behavior among some students as there are among adults, but if a student is capable of learning in positive ways, he should be 
accepted in positive ways. Through this type of association librarians stand only to gain.

Finally, a willingness to seek the opinions of student workers and then to listen to them is a major step in finding that "responsible voice." In all situations librarians should open lines for communicating, caring always about what student assistants have to say, considering carefully their proposals for solving problems, and, perhaps most important, assuming with them jointly a responsibility for the character of the library in which they work to achieve well-balanced and integrated service. Order and progress in library management does not just happen; it evolves through thoughtful, critical analysis and improved understanding, and after objective consideration of the alternatives available which may lead to better direction.

Student assistants in college and university libraries have a stake in this direction, and it is doubtful that any library, as a major resource for teaching and learning, can reach a maximum level of service without full utilization of the capabilities, opinions, talents, and background of capable part-time student employees as well as of its fulltime staff.

Librarians are in the business of education and in developing people for the future of the profession. Regardless of day-to-day commitments and pressures, they should apply the widest possible latitude to their utilization of student assistants if they aspire successfully to accomplish their goals. 